\title{
Bingöl ilindeki etlik piliç işletmelerinin teknik özellikleri*
}

\author{
Hakan İNCi ${ }^{\circledR} 1$, Bilal YíĞiT ${ }^{\circledR}$ 1, Ersin KARAKAYA ${ }^{\circledR 2}$ \\ 1Bingöl Üniversitesi Ziraat Fakültesi Zootekni Bölümü Bingöl \\ ${ }^{2}$ Bingöl Üniversitesi Ziraat Fakültesi Tarım Ekonomisi Bölümü, Bingöl
}

\begin{abstract}
*Bu çalıșma yüksek lisans tezinden üretilmiș olup, Bingöl Üniversitesi Ziraat Fakültesi ile Bingöl İl Gıda Tarım ve Hayvancllık Müdürlüğü arasında 07.04.2018 tarihinde imzalanan Ortak Araştırma ve Geliştirme (AR-GE) Proje Protokolü çerçevesinde yürütücülüğü Doç. Dr. Hakan İNCİ tarafından yapılan "Bingöl ilindeki etlik piliç işletmelerinin teknik ve yapısal özellikleri" isimli projenin bir kısmıdır.
\end{abstract}

Alınış tarihi: 1 Mart 2019, Kabul tarihi: 25 Eylül 2019

Sorumlu yazar: Ersin KARAKAYA, e-posta: karakayaersin@hotmail.com

Öz

$\mathrm{Bu}$ araștırma, Bingöl ilindeki etlik piliç yetiștiriciliğinin teknik özelliklerinin incelenerek, sorunlarının tespit edilmesi ve çözüm önerilerinin getirilmesi amacıyla yapılmıştır. Araştırma materyalini toplam 9 adet broiler işletmesi oluşturmuştur. Araştırma sonuçlarına göre, işletmelerin tamamında mülkiyetin kendilerine ait olduğu ve 1-2 adet kümesten oluştuğu saptanmıştır. İncelenen işletmelerde mevcut kapasite $30 \quad 042$ adet/devir, kapasite kullanım oranı ise \%82.7 olarak belirlenmiștir. Üreticilerin yaş ortalaması 50.3, \%44.5'i ilkokul mezunu ve tamaminın deneyim süresi 3-4 yıl olarak hesaplanmıştır. Kümeslerin tamamında askılı yuvarlak yemlik tipinin ve damlalıklı nipel suluk tipinin kullanıldığı saptanmıştır. İncelenen kümeslerde ısıtma materyali olarak \%80 oranında kömür, havalandırmada ise $\% 80$ oranında fan kullanıldığı gözlenmiştir. Kümeste $\mathrm{m}^{2}$ 'ye konulan hayvan sayısı 12 adet, hayvan başına tüketilen yem ortalama $3.9 \mathrm{~kg}$ ve 40-45 günlük canlı ağırlık ortalaması $2.1 \mathrm{~kg}$ olarak belirlenmiştir. İncelenen kümeslerde kullanılan canlı materyal dış kaynaklı hibrit olup, bir dönemdeki ölüm oranı \%5-6 civarındadır. Bingöl ili broiler yetiştiriciliğinin Türkiye geneline benzer biçimde sözleșmeli yetiștiricilik koșullarında gerçekleștiği görülmüștür. Bingöl ili broiler yetiștiricilerinin temel sorunlarının daha çok yem ve hastalıklar konusunda olduğu sonucuna varılmıştır. Üretimi artırmak ve ildeki yetiştiricilerin sorunlarının çözümü için, üreticilerin hastalıklar konusunda eğitilmesi ve yem temini konusunda desteklenmesi gerekmektedir.
Anahtar kelimeler: Bingöl, broiler işletmesi, üretici, bakım-besleme, kapasite

\section{A research on technical and structural properties of broiler farms in Bingol province}

\section{Abstract}

The aim of this study was to investigate the technical and structural characteristics of broiler breeding, to determine the problems and to propose solutions in the province of Bingol. Research material consisted of a total of 9 broiler business. According to the survey; all of the business is his property and poultry houses were found to be 1-2 pieces the whole of enterprises. Capacity is generally 30042 total / rev in studied broiler poultry. The capacity utilization rate, are defined as $82.7 \%$ in general businesses. The average age of breeders, are $50.3,44.5 \%$ of breeders are primary school graduates and the experience period of all producers was calculated as 3-4 years. It was found that the type of hanging round feed and dropper nipple waterers type are used all of the poultry houses. The ratio of used stove as a heating material is $80 \%$, the rate of used fan as a ventilation is $80 \%$. The ratio of the stocking density of broilers were 12 birds/square meter, the amount of feed intake for a broiler were $3.9 \mathrm{~kg}$ and the avarage live weight was $2.1 \mathrm{~kg}$ at $40-45$ days of age. Broiler houses were mostly use hybrid chicks of foreign orijin and mortality was founded $5-6 \%$ in one period. it was determined that Bingol province of broiler breeding is in a similar manner to Turkey general conditions of contract farming. The main 
problems of the all breeders in Bingol are feed and disease. In order to increase production and solve the problems of the breeders in the province, the producers should be educated on diseases and supported in the supply of feed.

Key words: Bingol, broiler farm, producer, management-feeding, capacity

\section{Giriş}

Ekonomik kalkınmada tarımın birinci ve en önemli fonksiyonu, ülke insanlarının gıda maddeleri ihtiyacını karşılamaktır. Gıda maddeleri ihtiyacının karşılanması çok eski çağlardan beri üzerinde durulan önemli konulardan biridir (Cinemre ve Kılıç, 2015). Yeterli ve dengeli bir beslenme için biyolojik değeri yüksek gıdaların, yeterli miktarda tüketilmesi gerekmektedir. Hayvansal proteinlerin biyolojik değerleri bitkisel proteinlere göre daha yüksek olduğu için, yeterli ve dengeli beslenmede hayvansal ürünler birinci sırayı almaktadır (Çiçekgil ve Yazıcı, 2016). Tavuk eti ve yumurtasının yüksek besin değerine sahip olması, üretim süresinin kısa olması, göreli olarak üretim maliyetinin düşük olması sebebiyle üretim ve tüketim açısından son derece avantajlı olduğu söylenebilir (Şahin ve Yıldırım 2001; Boyraz 2016; İkikat Tümer ve ark., 2018). Tavukçuluk, doğal koşullara bağımlılığı bitkisel üretime kıyasla daha az olması sebebiyle, dünyanın her yerinde üretim imkânı olan tarımsal faaliyetlerden biridir (Açll 1966; Şahin ve Yıldırım 2001; Boyraz 2016). Çicekgil ve Yazıcı (2016) Türkiye tavuk sektörünün sürekli gelișen, ihracatını hızlı bir șekilde yükselten, yoğun istihdam olușturan ve tarımı destekleyici yapısıyla ekonomiye önemli ölçüde katma değer sağlayan sektörler içinde yer aldığını bildirmişlerdir. Etlik piliçte üretici, herhangi bir firmadan bağımsız olarak veya piyasada çoğunlukla uygulanan çeşitli entegre firmalara bağımlı olarak üretime başlamaktadır. Üreticinin bağımsız olarak üretime başlaması durumunda ise, bütün üretim girdileri için değişik firmalarla ilişki kurarak etlik piliç üretimi yapmak durumundadır. Entegre firmalarla sözleșme imzalayarak üretime başlaması durumunda, üretici yalnızca civcivleri büyütüp kesimlik piliç oluncaya kadarki bakım ve idaresini yapar, üretim girdileri entegre firma tarafından karşılanır. Et tavukçuluğunda civcivler damızlıkçı ișletmeden alınır, 35-42 gün süreyle bu civcivler büyütülür ve satılır. Daha sonra üretici kümesini temizler, dezenfekte eder ve yeni civcivler alıp yeni bir üretime başlar. Yılda 4 ile 7 dönem üretim yapılabilmektedir. Et tavukçuluğunda, genelde hayvanlar zeminde talaş altllk üzerinde barındırılır, kafes pek kullanılmaz ve yemlik ve suluklar hayvanların önüne yukarıdan sarkitılır (Anonim 2016; Boyraz 2016). USDA (2016) verilerine göre, dünya piliç eti üretimi 89545 bin ton olup, Türkiye'de piliç eti üretimi dünya üretiminin yaklaşık \%2 si (1900 bin ton) kadardır (BESD-BİR 2016). Dünya tavuk eti üretimi 2016 yllında, 2005 yllına göre $\% 52$ artarak, 107 milyon tona yükselmiştir. Dünya tavuk eti üretimi ve ihracatında $A B D$ ve Brezilya en büyük paya sahip ülkelerdir ve 2016 yll itibariyle üretimin \%17'si ABD, \%13'ü Brezilya ve $\% 12$ 'si Çin olmak üzere toplam $\% 42$ 'si bu 3 ülke tarafından karşılanmıştır. Rusya ise üretimin \%4'ünü karşılarken, Türkiye 2016 yılında 1,9 milyon ton tavuk eti üretimi ile 12. sırada yer almıştır (FAO, 2018).

Türkiye'de 2016 yllı itibariyle toplam hayvansal üretim değeri 152 milyar TL olarak gerçekleşmiştir. 2016 yılı canlı hayvan üretim değeri 89,9 milyar TL olup; bunun 4,9 milyar TL ile \%5,5'lik kısmını kanatlı eti oluşturmaktadır. 2016 yılı hayvansal ürün üretim değeri ise 62,2 milyar TL olup; bunun 5,6 milyar TL ile \%9.0'luk kısmını ise yumurta oluşturmaktadır (TÜIK, 2018). Türkiye'de kanatlı grubuna tavuk, hindi, kaz, ördek gibi çeşitli hayvan türleri girmekle beraber, eti ve yumurtası için ağırlıklı olarak tavuk yetiştirilmektedir. 2017 yılında kanatlı hayvanların \%64'ünü et tavuğu, \%35'ini yumurta tavuğu ile sadece \%1'lik kısmını ise diğerleri oluşturmuştur (TAGEM, 2018). Türkiye'de 2017 yılında et tavuğu sayısı 221 milyon adet iken, TRB1 bölgesi (Malatya, Elazığ, Bingöl ve Tunceli) et tavuğu sayısı (6 milyon adet) Türkiye et tavuğu sayısının yaklaşık \%3'ünü, Bingöl et tavuğu sayısı (288 bin adet) ise TRB1 bölgesi et tavuğunun yaklaşık \%5'ini oluşturmaktadır. Kesilen tavuk sayısı 105 bin adet, tavuk eti üretimi 185 bin ton ve üretilen broiler civcivi sayısı ise 112 bin adettir. (TÜIK 2017).

Bu çalışma, Bingöl ili merkez ve ilçelerinde etlik piliç üretimi yapan işletmelerin teknik özelliklerini ortaya koymak amacıyla yapılmıştır. Çalışmada, Bingöl ili merkez ilçesine bağlı köylerde bulunan etlik piliç işletmelerinde üreticilerin sorunlarını belirlemek ve çözüm yollarını ortaya koymak hedeflenmiştir.

\section{Materyal ve Metot}

Bu araştırmanın ana materyalini, Bingöl ili merkez ilçesinde faaliyet gösteren ve $\% 50$ Tarım ve Orman Bakanlığı desteği ile kurulan işletme sahipleri ile yapilan anket sonucunda toplanan veriler oluşturmuştur. 
Araştırmanın ikincil verileri, Bingöl İl Tarım ve Orman Müdürlüğü, Türkiye İstatistik Kurumu (TÜIK), Gıda ve Tarım Örgütü (FAO), Beyaz Et Sanayicileri Birliği (Besd-Bir)'den sağlanan konu ile ilgili yapılmış çalışmalar, yerli ve yabancı yayınlar, konu üzerinde daha önce yapılmış olan araștırma sonuçları ve ilgili web sayfaları kullanılarak elde edilmiştir.

Anket çalışmaları, Bingöl ili merkez ilçesinde, 2018 yılı Mayıs-Ağustos döneminde üreticilerle yüz yüze görüşmek suretiyle yapılmıştır. Araştırmanın materyalini oluşturan broiler işletmelerin ildeki toplam sayısı, Tarım İl Müdürlügünden alınan bilgiye göre merkez ilçesi Garip köyünde 5, Göltepesi köyünde 1, Dikköyünde 2 ve Gümüşlü köyünde1 adet olmak üzere toplam 9 adet işletmenin tamamıla anket yapılmıştır. Verilerin istatistiki açıdan değerlendirilmesinde SPSS (2009) programı kullanılmıștır.

\section{Bulgular ve Tartışma}

\section{İşletmelerin genel özellikleri}

İşletmelerin genel özelliklerine ait bilgiler çizelge 1 'de verilmiştir. İncelenen işletmelerin tamamının 2015 yılında kurulduğu, 4'ünün şahsa (\%44.5) 5'inin ise (\%55.5) firmaya ait olduğu ve işletmelerin tamamının firmayla tavuk eti üzerinden para alarak sözleşmeli olduğu belirlenmiştir. Boyraz (2016)'ın Malatya'da yapmış olduğu çalışmada, işletmelerin \%94.8'inin șahsa ait olmakla birlikte özel bir firmayla sözleșmeli üretim yaptığı, \%3.8'inin kendi firmasına ve \%1.4'ünün șahsa ait olarak üretim yaptığı bildirilmiștir. İşletmenin il merkezine olan uzaklı̆̆ı, nakliye masraflarının düșürülmesi ve pazarlama açısından önemli bir konudur. Çalışmada incelenen işletmelerin Bingöl iline olan uzaklığl, işletmelerin 3'ünde (\%33.3) $10 \mathrm{~km}$ ve daha az, 4'ünde (\%44.5) 11-20 km arasinda ve 2'sinde (\%22.2) $21 \mathrm{~km}$ 'den fazla olarak tespit edilmiştir. Yüzbaşı (2012), tarafından yapılmış olan araştırmada, işletmelerin \%15'inde Bandırma merkezine olan uzaklığın 5-10 km arasında, $\% 52$ 'sinde 10-20 km arasinda ve \%33'ünde 20-30 km arasında olduğunu bildirmiștir. Boyraz (2016) tarafından yapılan çalışmada, incelenen kümeslerin Malatya iline olan uzaklığı, işletmelerin \%29.8'inde $21 \mathrm{~km}$ ' den az, \%48'inde 21-39 km arasında ve \%22.2'sinde 39 km'den fazladır. Çalışmamız Yüzbaşı (2012)'nın bulgulariyla benzer, Boyraz (2016)'ın bulguları ile farklı bir sonuç ortaya koymuş olup, pazarlama ve nakliye masraflarının azaltılması noktasında çalışmamızda incelenen işletmelerin
Malatya'daki işletmelere göre avantajlı olduğu düşünülebilir. Anket yapılan işletmelerde arazisi 610 dönüm olan işletmelerin sayısı 2 (\%22.2), 10-15 dönüm arazisi olan işletmelerin sayısı 5 (\%55.5) ve 15 dönüm ve üzeri arazisi olan işletmelerin sayısı ise 2 (\%22.2) adet olarak bulunmuştur. Yenilmez (2005) tarafından Çukurova yöresinde yapılan çalışmada, anket yapılan işletmelerin \%55.3'ünün 5 dekar ve daha az, \%14.5'inin 6-10 dekar ve \%30.2'sinin 10 dekardan fazla arazi varlığının olduğu saptanmıştır. Boyraz (2016) tarafından Malatya'da yapılan çalışmada ise, işletmelerin \%15.5'i 5 dekar ve daha az arazi, \%44.4'ü 6-10 dönüm arasında arazi, \%24.6'sı 10-15 dönüm arasında arazi ve \%15.5'i ise 15 dönüm ve daha fazla arazi varlığına sahip olarak belirlenmiştir. Çalışmamızın bu sonucu Yenilmez (2005) ile Boyraz (2016)'ın bulgulariyla farklılı göstermektedir. İşletmelerin 5'inin (\%55.5) kuruluş kapasitesinin 36 000 adet/dönem olduğu, 4'ünün ise (\%44.5) 35000 adet/dönem olduğu belirlenmiştir. Yenilmez (2005) Çukurova yöresindeki broiler işletmelerinde yaptığı bir araştırmada, anket yapılan kümeslerin \%34.6'sının 5000 ve daha az kapasitede olduğu, Türkyılmaz (2006) tarafından yapılan çalışmada, işletmelerin yaklaşık \%52'sinin $10 \quad 001-20 \quad 000$ kapasiteli olduğu, Yüzbaşı (2012) tarafından yapılan çalışmada, 10 000-20 000 adet/dönem kapasiteli kümeslerin \%68 ile ilk sırada olduğu, Boyraz (2016) tarafından yapılan çalışmada, $10 \quad 000-20 \quad 000$ adet/dönem kapasiteli kümeslerin 36 adetle (\%46.7) ilk sırada olduğu belirlenmiştir. Yeni (2012) yürütmüş olduğu çalışmada Bolu için 5001-10 000 kapasite oranını \%39 ile 1. sırada, Düzce için 10 00125000 kapasite oranını \%38 ile 1. sırada, Kocaeli için 10 001-25 000 kapasite oranını \%60 ile 1. sırada ve Sakarya için 10 001-25 000 kapasite oranını \%53 ile 1. sırada olarak saptamıştır. İşletmelerin tamamında bütün işletmelerin işletme sahibinin kendi mülkü olduğu ve işletmelerin tamamında kümes sayısının 1-2 adet olduğu belirlenmiştir. Boyraz (2016)'ın yapmış olduğu çalışmada, işletmelerin tamamının mülk durumunda ve tamamının 1-2 adet kümese sahip olduğu saptanmıştır. İşletmelerin konumu ve yönü incelenmiş ve işletmelerin 3'ünün (\%33.3) Doğu-Batı yönünde olduğu belirlenirken, 6'sının ise (\%66.6) diğer (Kuzey-Doğu) konum ve yönde olduğu, KuzeyGüney yönünde ise hiçbir ișletme olmadığl sonucu saptanmıştır. İşletmelerin 2'sinin (\%22.2) topoğrafik durumu eğimli, 7'sinin (\%77.7) düz olduğu ve 
topoğrafik durumu taşlık olan işletme olmadı̆̆ sonucu belirlenmiştir. İşletmelerin tamamında işçi çalıştırıldığı belirlenirken, 1-2 işçi çalıștıran işletme sayısı 6 (\%66.6), 3-4 işçi çalıştıran işletme sayısı 1 (\%11.1) ve 5 ve 5 den fazla işçi çalıștıran işletme sayısı ise 2 (\%22.2) adet olarak tespit edilmiștir. Türkyılmaz (2006) tarafından yapılan çalışmada, işletmelerin \%43.6'sının bir, işletmelerin \%24.2'sinin iki, işletmelerin \%4.8'inin üç işçi istihdam ettiği belirlenmiş olup, işletmelerin \%27.4'ünde ise hiçbir kiralık işgücü çalıştırılmadığı, tespit edilmiştir. Köse ve Durmuş (2014) Ordu ilindeki mevcut işletmelerin \%82.4'ünde 1 işçi, \%17.6'sında ise 2 işçi bulunduğunu bildirmişlerdir. Boyraz (2016)'ın yapmış olduğu çalışmada ise, işletmelerin \%58.5'inde hiçbir kiralık işgücü çalıştırılmadığı, işletmelerin \%37.6’sında 1-2 kişi ve işletmelerin \%3.9'unda 3-4 kişi istihdam edildiği belirlenmiştir. Çalışma bulguları, Türkyılmaz (2006), Köse ve Durmuş (2014) ve Boyraz (2016)'ın çalışma bulgularıyla farklılı göstermiştir. İşletmelerin 7'sinin diğer (kırsal kalkınma) ile finanse edildiği, 2'sinin ise banka kredisi ile finanse edildiği tespit edilmiştir. İşletmelerin 7'sinin yapım maliyeti 1200000 TL, 2'sinin ise 1350000 TL olarak belirlenmiştir. Türkyılmaz (2006) tarafından yapılan çalışmada, işletmelerin \%38.7'sinin kendi ekonomik kaynaklarını devreye soktukları, \%61.3'ünün ise krediye ihtiyaç duyduğu, Boyraz (2016) tarafından yapılan çalışmada ise, incelenen işletmelerin \%53.2'sinde işletmenin finansmanının banka kredisiyle, \%35'inde işletmenin finansmanının işletmecinin kendisi tarafından ve \%21.8'inde ise işletmenin finansmanının Tarım ve Kırsal Kalkınmayı Destekleme Kurumu (TKDK) tarafından sağlandığı belirlenmiştir. Çalışma bulguları itibariyle Türkyılmaz (2006) ve Boyraz (2016)'ın sonuçlarıyla farklılık göstermiştir.

\section{İşletmelerin üretim kapasiteleri}

İşletmelerde kapasite gruplarına göre; kurulu kapasite, kullanılan kapasite ve kapasite kullanım oranları Çizelge 2'de verilmiştir. İşletmelerin kapasite durumlarına ait değerler hesaplanırken üretim dönemine ait veriler kullanılmış, bir üretim dönemi içinde işletmelerin 6 devirle üretim yaptıkları, her devirde aynı sayıda hayvanla üretime başladıkları ve her devir sonunda aynı sayıda hayvanın kesime gittiği belirlenmiştir. Kullanılan kapasite değeri belirlenirken, üretim dönemi sonunda kesime giden canlı tavuk sayısı dikkate alınmıștır. Kapasite kullanım oranı ise kullanılan kapasitenin kurulu kapasiteye oranlanmasıyla bulunmuştur. İşletmeler genelinde kurulu kapasite ortalama olarak 35625 adet/devir, kullanılan kapasite 30042 adet/devir ve kapasite kullanım oranı ise \%82.7 olarak bulunmuştur. İncelenen işletmelerde 35000 kapasiteye sahip olanların, 36 000 kapasiteye sahip olan işletmelere nazaran kapasite kullanım oranlarının daha yüksek olduğu sonucu belirlenmiştir.

Çizelge 1. İşletmelerin genel özellikleri

\begin{tabular}{|c|c|c|}
\hline $\begin{array}{c}\text { İşletmelerin genel } \\
\text { özellikleri } \\
\text { İşletmenin aitlik } \\
\text { durumu* } \\
\end{array}$ & Sayı (Adet) & Oran (\%) \\
\hline $\begin{array}{c}\text { Şahis } \\
\text { Firma } \\
\text { Toplam }\end{array}$ & $\begin{array}{l}4 \\
5 \\
9\end{array}$ & $\begin{array}{c}44.4 \\
55.6 \\
100.0\end{array}$ \\
\hline $\begin{array}{c}\text { İsletmenin ile uzaklığı* } \\
\leq 10 \mathrm{~km} \\
11-20 \mathrm{~km} \\
\geq 21 \mathrm{~km} \\
\text { Toplam }\end{array}$ & $\begin{array}{l}3 \\
4 \\
2 \\
9 \\
\end{array}$ & $\begin{array}{c}33.3 \\
44.4 \\
22.3 \\
100.0 \\
\end{array}$ \\
\hline $\begin{array}{c}\text { İşletmenin arazi varlığı } \\
\text { 6-10 dönüm } \\
\text { 10-15 dönüm } \\
\geq 15 \text { dönüm } \\
\text { Toplam } \\
\end{array}$ & $\begin{array}{l}2 \\
5 \\
2 \\
9\end{array}$ & $\begin{array}{c}22.2 \\
55.6 \\
22.2 \\
100.0 \\
\end{array}$ \\
\hline $\begin{array}{c}\text { İşletmenin kuruluş } \\
\text { kapasitesi* } \\
35000 \text { adet } \\
36000 \text { adet } \\
\text { Toplam } \\
\end{array}$ & $\begin{array}{l}4 \\
5 \\
9\end{array}$ & $\begin{array}{c}44.4 \\
55.6 \\
100.0\end{array}$ \\
\hline $\begin{array}{c}\text { İşletmenin konumu ve } \\
\text { yönü* } \\
\text { Doğu-Batı } \\
\text { Diğer (Kuzey-Doğu) } \\
\text { Toplam } \\
\end{array}$ & $\begin{array}{l}3 \\
6 \\
9\end{array}$ & $\begin{array}{c}33.3 \\
66.7 \\
100.0\end{array}$ \\
\hline $\begin{array}{c}\text { İşletmenin kurulduğu } \\
\text { yerin topoğrafik } \\
\text { durumu* } \\
\text { Eğimli } \\
\text { Düz } \\
\text { Toplam } \\
\end{array}$ & $\begin{array}{l}2 \\
7 \\
9\end{array}$ & $\begin{array}{c}22.2 \\
77.8 \\
100.0\end{array}$ \\
\hline $\begin{array}{c}\text { İşletmede çalışan işçi } \\
\text { sayısı } \\
1-2 \text { kişi } \\
3-4 \text { kişi } \\
5 \text { kişi ve fazlası } \\
\text { Toplam } \\
\end{array}$ & $\begin{array}{l}6 \\
1 \\
2 \\
9\end{array}$ & $\begin{array}{c}66.7 \\
11.1 \\
22.2 \\
100.0\end{array}$ \\
\hline $\begin{array}{c}\text { İşletmenin finansman } \\
\text { şekli* } \\
\text { Banka kredisi } \\
\text { Diğer (Kırsal Kalkınma) } \\
\text { Toplam } \\
\end{array}$ & $\begin{array}{l}2 \\
7 \\
9\end{array}$ & $\begin{array}{c}22.2 \\
77.8 \\
100.0\end{array}$ \\
\hline $\begin{array}{c}\text { İsletmenin yapım } \\
\text { maliyeti* } \\
1200000 \mathrm{TL} \\
1350000 \mathrm{TL} \\
\text { Toplam } \\
\end{array}$ & $\begin{array}{l}7 \\
2 \\
9\end{array}$ & $\begin{array}{c}77.8 \\
22.2 \\
100.0\end{array}$ \\
\hline
\end{tabular}


Öztürk ve Durmuş (2002) tarafından yapılan bir çalışmada, Türkiye'de etlik piliç yetiştiriciliği yapan işletmelerde kapasite kullanım oranını \%71, Köse ve Durmuş (2014) yaptıkları bir çalışmada, Ordu'da kurulu işletmelerin kapasite kullanım oranının $\% 80.4$ ve Boyraz (2016) tarafindan yapılan çalışmada ise, kapasite kullanım oranı \%89 olarak belirlenmiştir. Çalışmada hesaplanan kapasite kullanım oranı Öztürk ve Durmuş (2002) ile Köse ve Durmuş (2014)'un çalışmalarındaki değerden yüksek, Boyraz (2016)'ın çalışmasındaki değerden düşük bulunmuştur.

Çizelge 2. İşletmelere ait kapasite bilgileri

\begin{tabular}{|c|c|c|c|c|}
\hline $\begin{array}{c}\text { Kapasite grupları } \\
\text { (Adet) }\end{array}$ & $\begin{array}{c}\text { İşletme sayısı } \\
\text { (Adet) }\end{array}$ & $\begin{array}{c}\text { Kurulu kapasite } \\
\text { (Adet/Devir) }\end{array}$ & $\begin{array}{c}\text { Kullanılan kapasite } \\
\text { (Adet/ Devir) }\end{array}$ & $\begin{array}{c}\text { Kapasite kullanım } \\
\text { oranı }(\%)\end{array}$ \\
\hline 35000 & 4 & 35000 & 32800 & 93.7 \\
\hline 36000 & 1 & 36000 & 26000 & 72.2 \\
\hline 36000 & 1 & 36000 & 26000 & 72.2 \\
\hline 36000 & 1 & 36000 & 27000 & 75.0 \\
\hline 36000 & 1 & 36000 & 30000 & 83.3 \\
\hline 36000 & 1 & 36000 & 32940 & 91.5 \\
\hline Ortalama/Toplam & 9 & $35625 / 215000$ & $30042 / 174740$ & 82.7 \\
\hline
\end{tabular}

\section{İşletme sahipleri ile ilgili bilgiler}

İşletme yöneticilerinin sosyo- ekonomik ve demografik özellikleri; ișletmelerin yönetim şekli, organizasyonu, teknolojik yeniliklerin benimsemesi ve uygulaması gibi bütün işletme faktörleri üzerinde son derece önemli bir etkiye sahiptir (Esengün 1990; Yeni 2012; Boyraz 2016). İşletme sahiplerine ait bilgiler Çizelge 3'te verilmiştir. Anket yapılan işletmecilerin \%55.5'i 50 yaşından küçük, \%44.5'i ise 50 yaş ve üzerinde olup, ortalama yaş 50.3'tür. İşletmecilerin tamamının okuryazar olduğu belirlenirken, ilkokul mezunu olan ișletmecilerin oranı $\% 44.5$, ortaokul mezunu olan ișletmecilerin oranı \%11.1, lise ve üniversite mezunu olan işletmecilerin oranı eșit ve \%22.2 olarak belirlenmiştir. Donar (1994) yürütmüş olduğu bir çalışmada, yetiştiricilerin \%71.9'unun eğitim seviyesini ilkokul mezunu olarak bildirmiştir. Yenilmez (2005) yaptığı araştırmada, işletmecilerin \%55.3'ünün ilkokul mezunu olduğunu rapor etmiştir. Türkyılmaz (2006) tarafından yapılan çalışmada, işletmecilerin \%56.5'inin ilkokul mezunu olduğu tespit edilmiştir. Çalışmanın bu sonuçları Donar (1994), Yenilmez (2005) ve Türkyılmaz (2006)'ın bulgularıyla uyumlu sonuçlar ortaya koymuş, bu çalışmaların genel sonuçları itibariyle, son zamanlarda eğitim seviyesi yüksek kişilerin tavukçulukla uğraştıkları kanısına varılmıştır. Başlangıçta tavukçuluk deneyimi olmayan işletmeci olmadığı, tavukçuluk deneyimi durumunun orta olduğunu ifade eden işletmeci oranı \%88.9 ve tavukçuluk deneyiminin iyi olduğunu ifade eden işletmeci oranı ise \%11.1 olarak bulunmuştur. Yenilmez (2005) yaptığı çalışmada, işletmecilerin çoğunun (\%73.6) başlangıçta bir deneyimi olmadığı sonucunu bildirmiştir. Boyraz (2016)'ın yapmış olduğu çalışmada, işletmecilerin \%92.2'si başlangıçta tavukçuluk deneyiminin olmadığını, \%7.8'i ise tavukçuluk deneyiminin iyi durumda olduğunu belirtmişlerdir. İncelenen işletmelerde başlangıçta tavukçuluk deneyimi orta seviyede olan işletmeci olmadığı tespit edilmiștir. İșletmecilerin tamamının 3-4 yıldır tavukçuluk yaptığı belirlenmiştir. Türkyılmaz (2006) yürüttüğü bir araștırmada, on yıldan fazla tavukçuluk yapan işletmecilerin oranını \%56.4 olarak on yıldan az tavukçuluk yapan işletmecilerin oranını ise \%43.6 olarak bildirmiştir. Malatya'da Boyraz (2016) tarafindan yapılan çalışmada ise, deneyim süresi 6 yıldan fazla olan işletmecilerin oranı, \%63.2 olarak tespit edilmiş, bunu sırasıyla \%17.1 ile 3-4 yıl deneyime sahip işletmeciler, \%10.5 ile 5-6 yll deneyime sahip işletmeciler ve \%9.2 ile 1-2 yll deneyime sahip işletmeciler izlediği belirlenmiştir. Çalışmamız bu sonucu itibariyle Türkyılmaz (2006) ve Boyraz (2016)'ın bulgularıyla farklı bir durum ortaya koymuş ve çalışmamıza katılan işletmecilerin deneyim süresi bakımından tecrübesiz oldukları kanısına varılmıştır. Tavukçuluk konusunda eğitim alan işletmecilerin oranı \%62.5, eğitim almayanların oranı ise \%37.5 olarak saptanmıştır. Yenilmez (2005) tarafından yaplan çalışmada, tavuk yetiştiriciliği konusunda herhangi bir eğitim almayan işletmecilerin oranı \%97.3, Boyraz (2016) tarafından yapılan çalışmada ise aynı oran \%92.3 olarak tespit edilmiştir. Çalışma bulguları Yenilmez (2005) ve Boyraz (2016)'ın çalışma bulgularından farklılık arz etmiştir. 
Çizelge 3. İşletme sahipleri ile ilgili bilgiler

\begin{tabular}{|c|c|c|}
\hline İşletme sahibi ile ilgili bilgiler & $\begin{array}{c}\text { Sayı } \\
\text { (Adet) }\end{array}$ & $\begin{array}{c}\text { Oran } \\
(\%)\end{array}$ \\
\hline Yas & & \\
\hline$<50$ yaş & 5 & 55.5 \\
\hline$\geq 50$ yaş & 4 & 44.5 \\
\hline Toplam & 9 & 100.0 \\
\hline Ortalama & \multicolumn{2}{|c|}{50,3} \\
\hline \multicolumn{3}{|l|}{ Eğitim durumu } \\
\hline Tahsili yok & 0 & 0 \\
\hline İlkokul & 4 & 44.5 \\
\hline Ortaokul & 1 & 11.1 \\
\hline Lise & 2 & 22.2 \\
\hline Üniversite & 2 & 22.2 \\
\hline Toplam & 9 & 100.0 \\
\hline \multicolumn{3}{|l|}{ Başlangıçta tavukçuluk } \\
\hline deneyimi olup olmadığı & 0 & 0 \\
\hline Yok & 8 & 88.9 \\
\hline Orta & $\begin{array}{l}8 \\
1\end{array}$ & 11.1 \\
\hline $\begin{array}{l}\text { İyi } \\
\text { Toplam }\end{array}$ & 9 & 100.0 \\
\hline \multicolumn{3}{|l|}{ Tavuk $\quad$ yetiştiriciliği } \\
\hline \multicolumn{3}{|l|}{ konusunda eğitim alıp } \\
\hline almama durumu & 5 & 54,5 \\
\hline Aldım & 4 & 44,5 \\
\hline Almadım & 9 & 100.0 \\
\hline Toplam & & \\
\hline
\end{tabular}

\section{İşletmelere ait kümeslerin teknik ve yapısal özellikleri}

İncelenen işletmelerde kümeslerin eni ortalama $16.25 \mathrm{~m}$, kümeslerin boyu $141.38 \mathrm{~m}$ ve duvar yüksekliği ise $2.37 \mathrm{~m}$ olarak bulunmuştur. İșletmelerin \%37.5'inde kümes planlarının özel firma tarafından \%62.5'inde ise diğer kurumlar (TKDK, Devlet daireleri) tarafından sağlandığı belirlenmiștir. İncelenen işletmelerin tamamında 1 adet kümes olduğu ve kümeslerin 2015 yılında yapıldığı belirlenmiştir. Kümeslerin \%75'inin prefabrik, \%25'inin ise betonarme olduğu tespit edilmiştir. İncelenen kümeslerin \%75'inin çatı malzemesinin galvanizli sac olduğu, \%25'inin ise panel çatı olduğu, \%62.5'inin duvar malzemesinin bims ısı yalıtımlı, \%37.5'inin prefabrik olduğu ve kümeslerin tamamının pencere malzemesinin standart olduğu sonucu tespit edilmiștir. Daha önce yapılan çalışmalarda kümes genişlikleri Yenilmez (2005) tarafından 12 m'den küçük, Yüzbaşı (2012) tarafından 10 m'den küçük ve Boyraz (2016) tarafından ise $12-15 \mathrm{~m}$ arasında belirlenmiştir. Çalışmada bulduğumuz değer diğer çalışma sonuçlarından yüksek çıkmıștır. Yenilmez (2005) ve Yüzbaşı (2012) tarafından yapılan çalışmalarda kümeslerin uzunluğunun genel olarak 100 m'den küçük olduğu, Boyraz (2016) tarafından yapılan çalışmada ise kümeslerin uzunluğunun genel olarak
100-150 m arasında olduğu tespit edilmiştir. Çalıșma bulguları Yenilmez (2005) ve Yüzbașı (2012)'nın çalışma bulgularıyla farklı, Boyraz (2016)'ın çalışma bulgularıyla benzer sonuç ortaya koymuştur. Yenilmez (2005) yaptığı araştırmada, duvar yüksekliği 2.5 m'den büyük olan kümes oranını \%62.9 olarak, Yüzbaşı (2012) yaptığı çalışmada, duvar yüksekliği 2.5 m'den büyük olan kümes oranını \%71 olarak bildirmiştir. Malatya'da yapılan bir çalışmada ise kümeslerin \%80.6'sında duvar yüksekliği 2.25 m’ye eşit veya daha büyük olarak saptanmıştır. Kümeslerde yan duvar yüksekliğinin isı dengesi ve havalandırma açısından önemli olduğu, duvar yüksekliği arttıkça kondüksiyon ile olan ısı kayıplarının da artacağı düşünüldüğünde, çalışmada bulduğumuz değer Yenilmez (2005) Yüzbaşı (2012) ve Boyraz (2016)'ın çalışmalarında buldukları değerden küçük ve ısı dengesi ve havalandırma açısından daha avantajlı olduğu belirlenmiştir. Yenilmez (2005) ve Boyraz (2016) tarafindan yapılan çalışmalarda kümes planlarının daha çok işletmecinin kendisi tarafından sağlandığı tespit edilmiş, çalışma bulguları Yenilmez ve Boyraz'ın çalışma bulgularıyla tamamen farklı sonuç ortaya koymuştur. Yenilmez (2005) yapmış olduğu bir çalışmada, kümeslerin büyük bir kısmının çatı örtü materyali olarak çinko+cam yünü tercih ettiğini belirlemiştir. Yüzbaşı (2012) yaptığı çalışmada, çatı kaplama materyali olarak kümeslerin \%92' sinde eternit, kullanıldığını bildirmiştir. Yapılan başka bir çalışmada, incelenen kümeslerde çatı malzemesi çoğunlukla (\%82) oranında sandviç panel olarak belirlenmiştir (Boyraz 2016). Çalışma bulguları diğer literatür bulgularıyla farklı sonuç ortaya koymuş bunun nedeninin çatı malzemesinin kullanımını etkileyen etkenler olduğu kanısına varılmıştır. Daha önce Alagöz (1983), Kayral ve Kayral (1985), Gülbahar (1993), Arıç (1996) ve Küçükaydın (1996) tarafından yapılmış olan çalışmalarda kümeslerin duvar malzemesinin briket olduğu, Noyan (1996) tarafından yapılan çalışmada, kümeslerin duvar malzemesinin taş olduğu ve Boyraz (2016)'ın yaptığı çalışmada ise kümeslerin duvar malzemesinin tuğla olduğu sonucu bildirilmiştir. Diğer çalışma sonuçları arasında paralellik olmasına karşın bizim çalışma sonuçlarımız diğer çalışmalardan farklı bir sonuç ortaya koymuştur. İncelenen işletmelerin tamamında bütün dönemler itibariyle askılı yuvarlak yemlik kullanıldığı belirlenmiştir. Civciv döneminde yemlik sayısı 150-170 arasında değișmekte ve ortalama 154 adet olarak belirlenirken, kümeslerin $\% 80$ 'inde 150 adet, \%20'sinde ise 170 adet yemlik 
olduğu sonucu belirlenmiștir. Kümeslerin tamamında yem tüketim formu toz olarak belirlenmiştir. Büyütme ve kesim döneminde kümeslerin tamamında yem tüketim formu pelet olarak saptanmıș, büyütme döneminde yemlik sayısının 300-680 adet arasında değiştiği ve ortalama 574 adet olduğu, kesim döneminde ise ortalama 615 adet olduğu saptanmıştır. İncelenen ișletmelerin tamamında kümeslerde bütün dönemlerde damlalıklı nipel tipi suluklar kullanıldığ saptanmıștır. Civciv döneminde 120-160 adet arasında ve ortalama 146 adet, büyütme ve kesim döneminde ise 2250-2520 adet ve ortalama 2454 adet suluk kullanıldığı belirlenmiştir. Daha önce yapılmış olan çalışmalarda, Donar (1994) işletmelerin büyük bir kısmında $(\% 81,8)$ silindir tipinde metalden yapılmış askılı yemliklerin kullanıldığını, Arıç (1996) kümeslerin \%57'sinde tam otomatik yemliklerin kullanıldığını, Erdem (1996) kümeslerin \%81'inde askılı tüp yemliklerin, Yenilmez (2005) incelenen kümeslerin \%40,3'ünde zincir tipi yemliklerin kullanıldığını, Yüzbaşı (2012) kümeslerde yemliklerin tamamının otomatik olup, spiral tipte olduğunu, Boyraz (2016) kümeslerin tamamında askılı yuvarlak yemlik tiplerinin kullanıldığını bildirmişlerdir. Etlik piliçlerin besin madde tüketim performansını arttırmak için yemlerin toz yerine pelet veya granül formda etlik piliçlere verilmesi daha etkilidir (Nir 1991; Ayhan vd 2000; Boyraz 2016). Etlik piliçlerin pelet yemi toz yeme göre daha fazla tükettikleri ve bunun sonucunda yüksek canlı ağırlık ve yemden yararlanma oranının daha yüksek olduğu sonucu belirlenmiștir (Kovan vd 1991; Ayhan vd 2000; Boyraz 2016). Boyraz (2016) tarafindan yürütülen çalışmada, kümeslerde genel ortalama itibariyle yemin tüketim şekli $\% 72,7$ oranında pelet olarak bildirilmiştir. Çalışmamızda elde edilen bulgular literatür bilgileri ile paralellik göstermiştir. Malatya'da Boyraz (2016) tarafindan yapılan çalışmada, incelenen kümeslerin tamamında damlalıklı nipel suluk tipinin kullanıldığı saptanmıştır. Donar (1994) kümeslerin tamamında tavandan sarkitılan askılı sulukların (çan tipi) kullanıldığını, Arıç (1996) ise çalışmasında kümeslerin \%88'inde tam otomatik sulukların kullanıldığını belirlemiştir. Yenilmez (2005)'in yapmış olduğu çalışmada kümeslerin \%5.7'sinde çan tipi suluk, \%58.5'inde damlalıksız nipel suluk ve \%35.8'inde damlalıklı nipel sulukların kullanıldığını saptamıștır. Yüzbaşı (2012)'nın bildirdiğine göre kümeslerdeki sulukların \%85'i nipel tipi, \%15'i çatıdan sarkıtmalı suluklardır. Çalışmamız, son zamanlarda yapılan çalışma sonuçlarıyla benzer bir sonuç ortaya koymuştur. İşletmelerin \%50'sinde çeltik kavuzu saman ve talaşın birlikte kullanıldığı, \%25'inde sadece çeltik kavuzunun kullanıldığı, \%12.5'inde ise çeltik kavuzu ile talaşın birlikte kullanıldığ 1 ve \%12.5'inde ise sadece samanın kullanıldığı tespit edilmiştir. Kümeslerde bir dönemde işletmelerin \%50'sinde 6 ton altlık materyali, \%37.5'inde 6.5 ton ve $\% 12.5^{\prime}$ inde ise 7 ton altlık materyali kullanıldığı belirlenmiştir. Boyraz (2016) tarafindan Malatya'da yapılan çalışmada, kümeslerde genel ortalama itibariyle \%93.1 oranında altlık materyali olarak talaşın kullanıldığı sonucu bildirilmiştir. İpek vd (2002) kümeslerde kullanılan altlık materyallerinin etlik piliç gelişimini önemli düzeyde etkilediğini, etlik piliç üretiminde sık kullanılan altlık materyallerinden talaş ve çeltik kavuzunun zor bulunmasının ve fiyatının yüksek olmasının üreticileri güç durumda bıraktığını, bu açıdan samanın, ucuz ve kolay temin edilmesi ayrıca etlik piliçlerin verim özelikleri açısından olumlu etkileri olduğu için avantajlı olduğunu bildirmişlerdir. Çalışma bulguları diğer literatür bulgularıyla farklı sonuç ortaya koymuştur.

Kümeslerde tüm dönemler itibariyle kömürle ısıtma şeklinin kullanım oranı \%80 ve radial fanla ısıtma şeklinin kullanım oranı ise \%20 olarak belirlenirken, ısıtma süresi full olarak belirlenmiştir. Kümeslerin \%80'inde havalandırma şeklinin fan, \%20'sinde ise tünel fan, egzoz fan şeklinde olduğu ve havalandırma süresinin full olduğu tespit edilmiştir. İncelenen kümeslerin tamamında aydınlatma șekli olarak led șeklinin ve aydınlatma süresi olarak ise 23 saat aydınlık 1 saat de karanlık şeklinin tercih edildiği sonucu bulunmuştur.

\section{İncelenen kümeslerde üretim ile ilgili bilgiler}

İncelenen kümeslerin tamamında Ross 308 hibritinin yetiştirildiği belirlenmiştir. Kümeslerin tamamında üretimin 6 dönem olarak, hepsi içeri hepsi dışarı üretim şeklinde ve sürekli olarak yapıldığı saptanmıştır. İncelenen kümeslerin tamamında verim kaydının tutulduğu belirlenmiştir. Kümeslerin tamamında hibritin firmadan alındığı tespit edilmiştir. Kümeslerde besi süresinin 42-45 gün arasında değişmekte olduğu görülmüş, besi süresinin 42-45 gün olma oranı \%44.4 ile en yüksek değer olarak bulunmuştur. İncelenen kümeslerde besi sonu tavukların canlı ağırlıkları ve kesim ağırlıklarına ait değerler Çizelge 4'te verilmiștir. 
Tavukların canlı ağırlıklarının 2700-2850 g arasında değiştiği ve ortalama $2750 \mathrm{~g}$, karkas ağırlıklarının ise 2025-2250 g arasında ve ortalama 2122 g olduğu belirlenmiştir.

Çizelge 4. Besi sonu canlı ağırlık ve kesim ağırlığı

\begin{tabular}{lcc}
\hline & Canlı ağırlık (g) & Karkas ağırlı̆̆ $(\mathrm{g})$ \\
\hline Ortalama & 2750 & 2122 \\
Minimum & 2700 & 2025 \\
Maximum & 2850 & 2250 \\
\hline
\end{tabular}

İncelenen kümeslerin \%50'sinde kesimden 4-6 saat önce tavukların yemden kesildiği, \%37.5'inde 12 saat önce ve $\% 12.5$ 'inde ise kesimden 4 saat önce tavukların yemden kesildiği saptanmıștır. İncelenen kümeslerin tamamında $1 \mathrm{~m}^{2}$ alana konulan civciv sayısı 12 adet olarak belirlenmiştir. Analiz edilen kümeslerde bir dönemde tüketilen toplam yem miktarının 105-125 ton arasında değiștiği ve ortalama 117 ton olduğu saptanmıştır. İncelenen kümeslerde hayvan başına tüketilen yem miktarının 3-4 kg arasında değiștiği ve ortalama 3.9 kg olduğu belirlenmiştir. Arıç (1996) incelediği etlik piliç işletmelerinin \%44'ünde etlik piliç başına tüketilen yemi 3.7-3.9 kg ve \%51'inde 3.9-4.5 kg olarak belirlemiştir. Yapılan diğer bir çalışmada, etlik piliç başına tüketilen yemin anket yapılan kümeslerin büyük bir kısmında (\%93.7) 3.6-4.0 kg olduğu saptanmıştır (Yenilmez 2005). Boyraz (2016) yaptığ çalışmada, bir dönemde tüketilen toplam yem miktarının 45-150 ton arasında değiştiğini ve ortalama 84 ton olduğunu ve incelenen kümeslerde etlik piliç başına tüketilen yem miktarının ortalama $4.1 \mathrm{~kg}$ olduğunu belirlemiştir. Çalışma bulguları diğer çalışma bulgularıyla kısmen farklı kısmen de benzer sonuçlar ortaya koymuştur. Anket yapılan kümeslerde ölüm oranları \%37.1'inde \%4-5, $\% 42.8$ 'inde \%5-6, \%20.1'inde \%7 ve yukarı olarak ve ölümlerin daha çok kış aylarında görüldüğü belirlenmiștir. İncelenen kümeslerin tamamında sıcaklık stresine karşı alınan önlemde klima kullanıldığı ve kümeslerin \%25'inde hayvanlara suya veya yeme vitamin ilavesinin olduğu \%75'inde ise hiçbir katkı maddesi ilavesinin olmadığı belirlenmiştir. Yenilmez (2005) yaptığı araştırmada, incelenen kümeslerin \%16.4'ünde sıcaklık stresine karşı herhangi bir katkı maddesi kullanılmadı ̆̆l, \%77.4'ünde yemlere vitamin eklendiği tespit edilmiștir. İncelenen kümeslerin \%43.3'ünde sıcaklık stresine karşı herhangi bir önlem alınmadığı, \%3.8'inde duş uygulaması (kümes çatısına yağmurlama şeklinde su uygulanması) yapıldığı, \%25.8'inde wet-ped uygulaması yapıldığı, \%15.1'inde fan uygulaması yapıldığı ve \%11.3'ünde başka yöntemlerin uygulandığı belirlemiştir. Yapılan diğer bir çalışmada da, yaz aylarında oldukça yüksek sıcaklıkların kaydedildiği bölgede işletmelerin \%96.8'inin petek-fan soğutma sistemini tercih ettiği gözlenmiştir (Türkyılmaz 2006). Malatya'da Boyraz (2016) tarafından yapılan çalışmada ise, incelenen kümeslerin tamamında sıcaklık stresine karşı alınan önlemde fanların kullanıldığı ve kümeslerin tamamında hayvanlara vitamin verildiği belirlenmiştir. Yapılan çalışmalarda sıcaklık stresine karşı alınan önlemde suya veya yeme vitamin ilave edilmesinin, yetiştiriciler tarafından en çok tercih edilen yöntem olarak uygulandığı sonucu ortaya çıkmıştır. Yapılan incelemeler sonucunda kümeslerin tamamında giriște ultra multi dezenfektan materyalinin bulunduğu ve her üretim dönemi sonunda dezenfeksiyonun yapıldığı tespit edilmiștir.

\section{Üretici sorunları}

İncelenen işletmelerde üreticilerin \%80'i sorun olarak yem ve \%20'si ise sorun olarak hastalıkları belirtmişlerdir. Yetiştiricilerin genel sorunları olarak kesimhane olmaması, yem maliyetleri ve ölüm çukuru sorunları belirlenirken, bu sorunların çözümü için yetiştiricilerin kesimhane yapılması, yem maliyetleri konusunda destekleme ve ölüm çukurlarının oluşturulması önerilerini ifade ettikleri belirlenmiştir. Öztürk ve Durmuş (2002) yaptıkları çalışmada, etlik piliç yetiştiricilerinin en önemli sorununun, üretimde kullanılan girdi fiyatlarının yüksek olmasından dolayı kar durumlarının yetersiz ya da hiç olmaması ve pazar sorunları olarak belirlemişlerdir. $\mathrm{Bu}$ sorunların yanı sıra diğer sorunlar ise; yem teminindeki problemler, hastalıklarla mücadele, örgütlenmedeki yetersizlikler, hayvanların gübrelerinin değerlendirilememesi olarak belirlenmiştir. Boyraz (2016) ise yapmış olduğu çalışmada, yetiştiricilerin $\% 87$ oranla eğitim sorunu, \%84.4 oranla kredi sorunu, \%1.3 oranla yem ve hastallk sorunu olduğunu bildirmiștir.

\section{Sonuç ve Öneriler}

Bingöl ili broiler yetiştiriciliğinin Türkiye geneline benzer biçimde sözleșmeli yetiștiricilik koșullarında gerçekleştiği belirlenmiştir. İşletmelerin tamamının 2015 yllında kurulduğu ve firmayla tavuk eti üzerinden para alarak anlaşması olduğu belirlenmiştir. İşletmelerin tamamında bütün işletmelerin işletme sahibinin kendi mülkü olduğu ve kümes sayısının 1-2 adet olduğu belirlenmiștir. 
İşletmeler genelinde kurulu kapasite ortalama olarak 35625 adet/devir, kullanılan kapasite $30 \quad 042$ adet/devir ve kapasite kullanım oranı ise \%82.7 olarak bulunmuștur. Pazarlama ve nakliye masraflarının azaltılması noktasında çalışmamızda incelenen işletmelerin il merkezine olan uzaklıklarının uygun olduğu, tavukçuluk konusunda gerek daha önce yapılmış olan ve gerekse bu çalışma genelinde son zamanlarda eğitim seviyesi yüksek kișilerin tavukçulukla uğraștıkları kanısına varılmıștır. İșletmecilerin tamamının 3-4 yıldır tavukçuluk yaptığı ve deneyim süresi bakımından tecrübesiz oldukları sonucu ortaya çıkmıştır. Genel olarak incelenen işletmelerde bulunan kümeslerin teknik ve yapısal özellikleri itibariyle daha önce yapılan çalışmalarda belirlenen sonuçlarla benzer olduğu tespit edilmiştir. Yetiştiricilerin genel sorunları olarak kesimhane olmaması, yem maliyetleri ve ölüm çukuru sorunları belirlenirken, bu sorunların çözümü için yetiştiricilerin kesimhane yapılması yem maliyetleri konusunda destekleme ve ölüm çukurlarının oluşturulması önerilerini ifade ettikleri belirlenmiştir. Çalışmamızda ortaya çıkan bu sonuçlar ışığında; Bingöl ilinde mevcut durumdaki üretici birliklerinin işlevsel açıdan revize edilmesi, sektörde çalışmak isteyen veya çalışmakta olan işçilerin eğitilmesi, yaşı genç eğitimli bireylere tavukçuluk eğitimi verilerek yetiştiricilik yaşının düşürülmesi ve eğitim seviyesinin yükseltilmesi uygun olacaktır. Üretimi artırmak ve ildeki yetiştiricilerinin sorunlarının çözümü için yetiştiriciler, damızlık işletmeleri, yem üreticileri, pazarlama organizasyonları ve konuyla ilgili devlet kuruluşları düzeyinde teknik ve ekonomik açıdan iyi bir organizasyona ihtiyaç vardır. Altlık materyali olarak talaşın yerine daha ucuz ve kolay bulunabilen samanın kullanılması üretim girdileri açısından işletmelere kazanç sağlayacaktır. İşletmelerin genelinde yemin firmadan alınması ve kredi sorunu durumu beraber düşünüldüğünde üreticilere bu noktada destekleme yapılması son derece önemlidir. Yem hammaddelerinin (soya, mısır, vb.) üretim miktarlarının artırılması sektörün üretim maliyetlerinin ve yem maliyet unsurunun payının azaltılabilmesi açısından önerilebilir.

\section{Kaynaklar}

Açıl, F., 1966. Türkiye Tavukçuluğunun İktisadi Cephesi. Ankara Üniversitesi, Ziraat Fakültesi, Yayın No: 252, Ankara s.100.
Alagöz, T., 1983. Çukurova Bölgesinde Tavukçuluk İşletmelerinde Kümeslerin Durumu, Özellikleri Ve Bölge İklim Koşullarına Uygun Planlarının Geliştirilmesi Üzerinde Bir Araştırma. Ç.Ü. Fen Bilimleri Enstitüsü Kültür teknik Anabilim Dalı (Doktora Tezi), Adana. 1983 s. 65 Adana.

Anonim, 2016. Kanatlı hayvancıllk sektör raporu. http://fka.gov.tr (erişim tarihi: 15.09.2018).

Arıç, H., 1996. Çukurova Bölgesi Broiler (Broiler) Yetiştiriciliğinin Yapısı Ve Sorunları. Çukurova Üniversitesi, Fen Bilimleri Enstitüsü, Zootekni Anabilim Dalı, Yüksek Lisans Tezi. s. 45 Adana.

Ayhan, V., Açıkgöz, Z., Özkan, K., Altan, Ö., Altan, A., Özkan, S., Akbas, Y., 2000. Farklı düzeyde besin madde içeren değişik formdaki karma yemlerin yüksek yaz sıcaklarında etlik piliç performansı ve karkas özellikleri üzerine etkileri. Turk J Vet Anim Sci, 24: 297-306.

Balce, A.O., Demir, S., 2007. İstatistik Ders Notları, Pamukkale Üniversitesi İktisadi ve İdari Bilimler Fakültesi, Ekonometri Bölümü, Denizli.

BESD BİR, 2016. Beyaz et sanayicileri ve damızlıç̧ları birliği derneği, 2016 verileri http://www.besdbir.org (erişim tarihi: 15.09.2018)

Boyraz, F.Ö., 2016. Malatya İlindeki Etlik Piliç İşletmelerinin Teknik Ve Yapısal Özellikleri. T.C. Bingöl Üniversitesi Fen Bilimleri Enstitüsü Yüksek Lisans Tezi Zootekni Anabilim Dalı. S. 81, Bingöl.

Cinemre, H.A., Kılıç, O., 2015. Tarım Ekonomisi. Ondokuz Mayıs Üniversitesi, Ziraat Fakültesi, Ders Kitabı No:11, (5.baskı), Samsun.

Çiçekgil, Z., Yazıcı, E., 2016. Türkiye'de tavuk yumurtası mevcut durumu ve üretim öngörüsü. TEAD 2(2): 26-34.

Donar, H., 1994. Adana-Mersin İllerinde Broiler Üretim Ekonomisi. Çukurova Üniversitesi Fen Bilimleri Enstitüsü Tarım Ekonomisi Anabilim Dalı, Yüksek Lisans Tezi, s. 55, Adana.

Erdem, M., 1996. Tarsus Köy-Tür A. Ş. Bağlantılı Broiler İşletmelerinin Verimlilik Yönünden Karșılaștırılması. Çukurova Üniversitesi Fen Bilimleri Enstitüsü Zootekni Anabilim Dalı Yüksek Lisans Tezi, s.104, Adana.

Esengün, K., 1990. Tokat İlinde Meyve Yetiștiriciliği Yapan İşletmelerin Ekonomik Durumu Ve İşletme Sonuçlarını Etkileyen Faktörlerin Değerlendirilmesi Üzerine Bir Araştırma. E.Ü. Fen Bilimleri Enstitüsü Tarım Ekonomisi Anabilim Dalı, (Yayınlanmamıș Doktora Tezi), Bornova-İzmir.

FAO, 2018. Food And Agriculture Organization of The United Natıons (FAO), www.fao.org. 
Gülbahar, A., 1993. Adana İli İlçe Ve Köylerinde Broiler (Broiler) Kümeslerinin Yapısal Yönden Mevcut Özellikleri İle Gelişme Durumlarının Belirlenmesi Üzerine Bir Araştırma. Çukurova Üniversitesi Fen Bilimleri Enstitüsü Tarımsal Yapılar ve Sulama Anabilim Dalı. Yüksek Lisans Tezi, s. 68, Adana.

İkikat Tümer, E., Ağır, H.B., Gürler, D. 2018. Broiler üretiminde üretici memnuniyetini etkileyen faktörler. Türk Tarım ve Doğa Bilimleri Dergisi, 5(4): 545-550.

İpek, A., Karabulut, A., Canbolat, Ö., Kalkan, H., 2002. Değişik altlık materyalinin etlik piliçlerin verim özellikleri ve altlık nemi üzerine etkileri. Uludağ Üniversitesi Ziraat Fakültesi Dergisi, 16(2): 137147.

Kayral, N., Kayral, G., 1985. Yeni Teknik Tavukçuluk. İnkılap Kitabevi, 3. Baskı, s.491 İstanbul.

Kovan, Ö., Yılmaz, S., Ergül, M., Bozkurt, M., 1991. Yem formunun kasaplık piliçlerde canlı ağırlık artısı ve yem tüketimine olan etkisi. Teknik Tavukçuluk Dergisi, 73: 3-15.

Köse, B., Durmuş, İ., 2014. Ordu ilindeki tavukçuluk işletmelerinin genel yapısı, sorunları ve çözüm önerileri. Akademik Ziraat Dergisi, 3(2): 89-94.

Küçükaydın, H., 1996. Hatay İlindeki Tavukçuluk İşletmelerinin Yapısal Özellikleri, Ekonomik Durumları, Sorunları Ve Çözüm Yolları. Mustafa Kemal Üniversitesi Fen Bilimleri Enstitüsü Zootekni Anabilim Dalı Yüksek Lisans Tezi, s. 48, Hatay.

Nir, I., 1991. Rasyonun fiziksel yapısının (Tekstürünün) etlik piliçlerde performans üzerine etkileri. Uluslararası Tavukçuluk Kongresi 22-25 Mayıs, İstanbul.

Noyan, M., 1996. Niğde Ve Kayseri İlleri Tavukçuluk İşletmelerinin Yapısal Özellikleri, Ekonomik Durumları, Sorunları ve Çözüm Yolları. Mustafa Kemal Üniversitesi Fen Bilimleri Enstitüsü
Zootekni Bölümü Yüksek Lisans Tezi, s. 78, Antakya.

Öztürk, F., Durmuş, İ., 2002. Türkiye'deki tavukçuluk işletmelerinin genel durumu. Tavukçuluk araştırma dergisi, (3)2, (http://arastirma.tarim.gov.tr).

Şahin, A., Yıldırım, İ., 2001. Van ilinde yumurta tavukçuluğu yapan işletmelerin ekonomik analizi. Yüzüncü Yll Üniversitesi, Ziraat Fakültesi, Tarım Bilimleri Dergisi, (J. Agric. Sci.) 11(2): 57-66.

TAGEM, 2018. Kanatlı Hayvancılık Sektör Politika Belgesi 2018-2022. (https://www.tarimorman.gov.tr).

TÜİK, 2017. Türkiye istatistik kurumu. Temel istatistikler, www.tuik.gov.tr, (erişim tarihi: 15.09. 2018).

TÜİK, 2018. Türkiye istatistik kurumu. Temel istatistikler, www.tuik.gov.tr, (erişim tarihi: 15.09. 2018).

Türkyılmaz, K.M., 2006. Aydın ili broyler işletmelerinin yapısal ve teknik durumu üzerine bir araștırma. YYÜ Veteriner Fakültesi Dergisi, 17(1-2): 65-69.

USDA, 2016. U.S. Department of Agriculture www.usda.gov, (erişim tarihi: 15.09.2018).

Yeni, A., 2012. Türkiye Broyler Sektöründe Üretim Kümeslerinin Ekonomik Yapısı Ve Etkinlik Analizi: Doğu Marmara Bölgesi Örneği. Atatürk Üniversitesi, Fen Bilimleri Enstitüsü, Tarım Ekonomisi Anabilim Dalı, Doktora Tezi, s. 129, Erzurum.

Yenilmez, F., 2005. Çukurova Yöresindeki (Adana Ve İçel İllerindeki) Broiler Ve Yumurta Tavuğu İşletmelerinin Yetiştiricilik, Teknik Ve Yapısal Özellikleri Üzerine Bir Araştırma. Çukurova Üniversitesi, Fen Bilimleri Enstitüsü, Zootekni Anabilim Dalı, Doktora Tezi, s. 143, Adana.

Yüzbaşı, Ş., 2012. Bandırma İlçesi Kasaplık Piliç İşletmelerinin Yapısal Ve Fonksiyonel Özellikleri. Ankara Üniversitesi, Fen Bilimleri Enstitüsü, Tarımsal Yapılar ve Sulama Anabilim Dalı, Yüksek Lisans Tezi, s. 116, Ankara. 